U. S. DEPARTMENT OF AGRICULTURE.

FARMERS' BULLE'TIN 401.

\title{
THE PROTECTION OF ORCHARDS IN THE PACIFIC NORTHWEST FROM SPRING FROSTS BY MEANS OF FIRES AND SMUDGES.
}

\author{
BY \\ P. J. O'GARA, \\ Scientific Assistant, Fruit-Disease Investigations, \\ Bureau of Plant Industry.
}

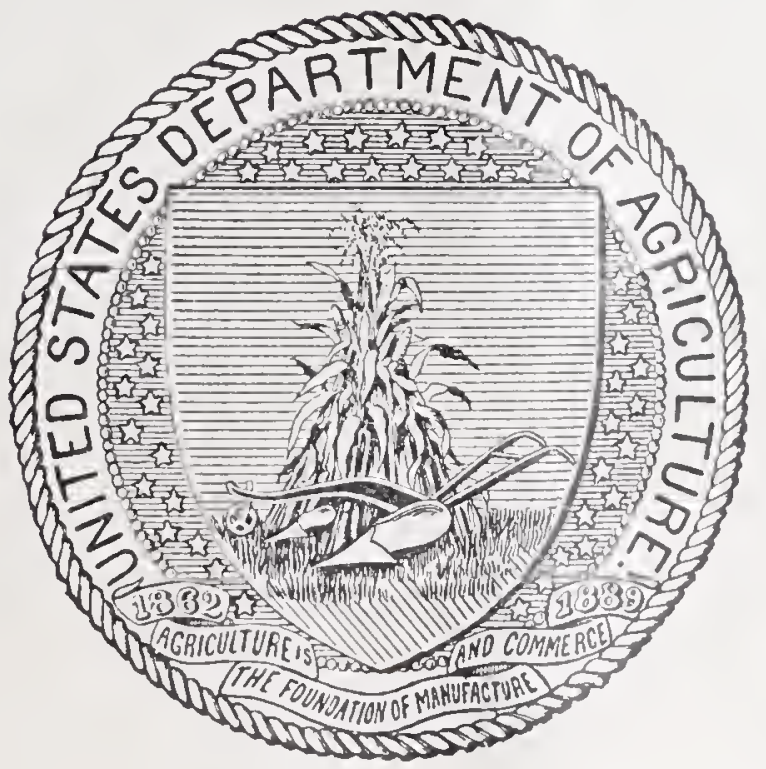

IVASHINGTON: 


\section{LETTER OF TRANSMITTAL.}

\section{U. S. Department of Agriculture, \\ Bureau of Plant Industiry, Office of the Chief, Washington, D. C., March 16, 1910.}

SIR: I have the honor to transmit and to recommend for publication as a Farmer's' Bulletin the accompanying manuscript, entitled "The Protection of Orchards in the Pacific Northwest from Spring Frosts by Means of Fires and Smudges," prepared by Mr. P. J. O'Gara, Scientific Assistant, Fruit-Disease Investigations.

A great deal of interest has developed in the last two or three years among fruit growers in the subject of protecting orchards artificially from frosts. A good many attempts have been made, particularly in the Rocky Mountain States and on the Pacific coast, in hoth deciduous and citrus orchards to ward off the frost damage by fires. At the request of fruit growers in the Rogue River Valley, where he has been assisting in the eradication of pear-blight, Mr. O'Gara undertook to help in solving the problem of frost prevention. Notwithstanding the favorable results obtained, it must be acknowledged that there is still considerable doubt as to the possibility under varied conditions of warding off the damage from frosts by fires, and also some question about its practicability in open orchards. Nevertheless, it is thought desirable to publish Mr. O'Gara's experiments and notes on this subject at the present time.

Respectfully,

Hon. James Wilson, Secretary of Agriculture.
G. H. Poweld, Acting Chief of Burcau. 


\section{CONTENTS.}

Iutroduction.... Page.

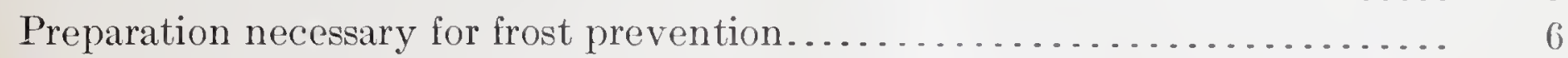

Materials to be used for fuel . . . . . . . . . . . . . . . . . . . . . . . . . 7

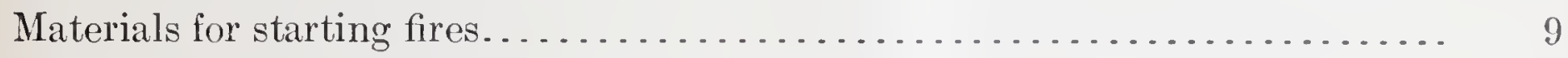

Manner of distributing the materials in the orchard................. 10

Quantity of material to be used for each fire...................... 11

Cost of materials for firing an acre................................ $\quad 12$

Necessity of understanding weather conditions.................... 13

Meteorological data obtained in the Rogue River Valley.................. 17

Weather conditions producing spring frosts in the Rogue River Valley...... 19

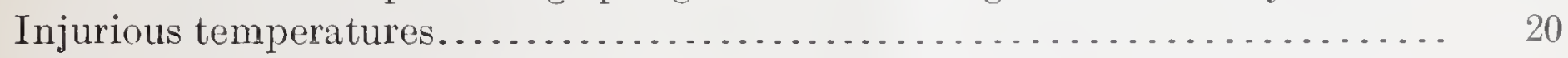

Results of the work.......................................... 20

Value of firing the orchards when the cost is compared with the value of the

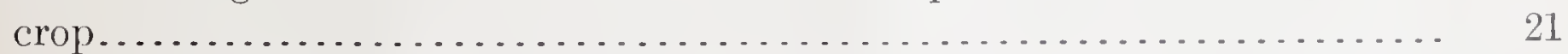

Practical suggestions on the use of the psychrometer and other meteorological

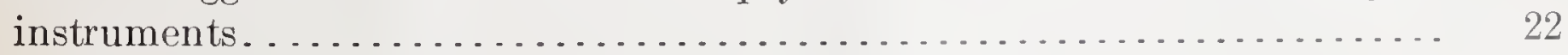

Conclusions................................................. 24 


\section{ILLUSTRATIONS.}

FIG. 1. Old fence rails used successfully for firing in saving the Bartlett pear crop of Mr. J. G. Gore in the Rogue River Valley, Oregron.........

2. Old rails used for firing to save the crop of the 7 -year-old apple orchard of Mr. J. G. Gore in the Rogue River Valley, Oregon.............

3. View in the Hollywood Orchards, Medford, Oreg., at 5 a. m., April 21, 1909, showing the smudging used to prevent frost injury..........

4. Paper sacks filled with shavings and sawdust saturated with crude fuel oil.... . . . . . . . . . . . . . . . . . . . . . . . . . . . .

5. A supply of paper sacks filled with shavings and saturated with crude fuel oil to be used for starting fires.........................

6. Arrangement of cordwood in the Yellow Newtown apple orchard of Mr. W. H. Brown in the Rogue River Valley, Oregon .............

7. Arrangement of cordwood in the Esopus orchard of Mr. W. II. Brown in the Rogue River Valley, Oregon.......................

8. Arrangement of material on the outside borders of the pear orchard of Mr. A. C. Allen in the Rogue River Valley, Oregon ..............

9. Fir cordwood with dry prunings used for firing in the apple orchard of Mr. W. II. Brown in the Rogue River Valley, Oregon ........... .

10. A homemade psychrometer showing the wet bulb extending below the frame, protected by a heavy wire loop.....................

11. Side view of a homemade psychrometer showing backs soldered to-

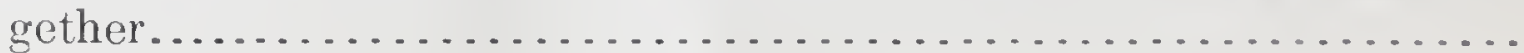

Page. 
I3 I' I.--565.

\section{THE PROTECTION OF ORCHARDS IN THE PACIIIC NORTHWEST FROM SPRING FROSTS BY MEANS OF FIRES AND SMUDGES.}

\section{INTRODUCTION.}

The object of this bulletin is to give, in considerable detail, the results of successful experiments and the methods employed in preventing frost injury by means of fires and smulges in the apple, peach, and pear orchards of the Rogue River Valley in souther'n Oregon during the spring of 1909.

This work was taken up by the writer at the earnest request of several growers, whose hearty cooperation made it possible to secure data of much value. It is believed that while every locality has its own peculiar factors and conditions, the results obtained in the Rogue River Valley wili be of more or less interest generally. The practicability of protecting orchards from frost injury has remained more or less an open question. The preventible annual losses throughout the country from low temperatures during the blooming period and for some time thereafter amount to millions of dollars. This is no doubt due to the facts that sufficient practical data and actual orchard experience which would serve as a guide for the fruit grower are wanting.

The excellent work done by the Riverside Ilorticultural Club, ${ }^{a}$ of Riverside, Cal., during the winter of 1897 and 1898 brought out many facts concerning frost prevention, but much of the apparatus used and many of the methods employed can not be adopted crenerally.

The important facts to be known by the grower are how to prepare for frost prevention, what materials to employ for fucl and the manner of distributing them in the orchards, what to luse in starting the fires and the method of preparing them, etc.

a Farmers' Bulletin 104, U. S. Dept. of Agriculture, cntitled "Y̌otes un Frust." 1908. 


\section{PREPARATION NECESSARY FOR FROST PREVENTION.}

It should be understood at the outset that frost prevention requires considerable preparation. It is impossible to get the material for fuel on the ground and have it distributed, especially where the orchards are large, after frost warnings are given out, since these warnings can not be given sufficiently in advance of the time necessary for firing in the orchards. Whatever the material to be used may be, it should be so placed that it may be readily distributed, and a sufficient quantity of it should be on hand in case it may become necessary to fire for a considerable length of time or in case several

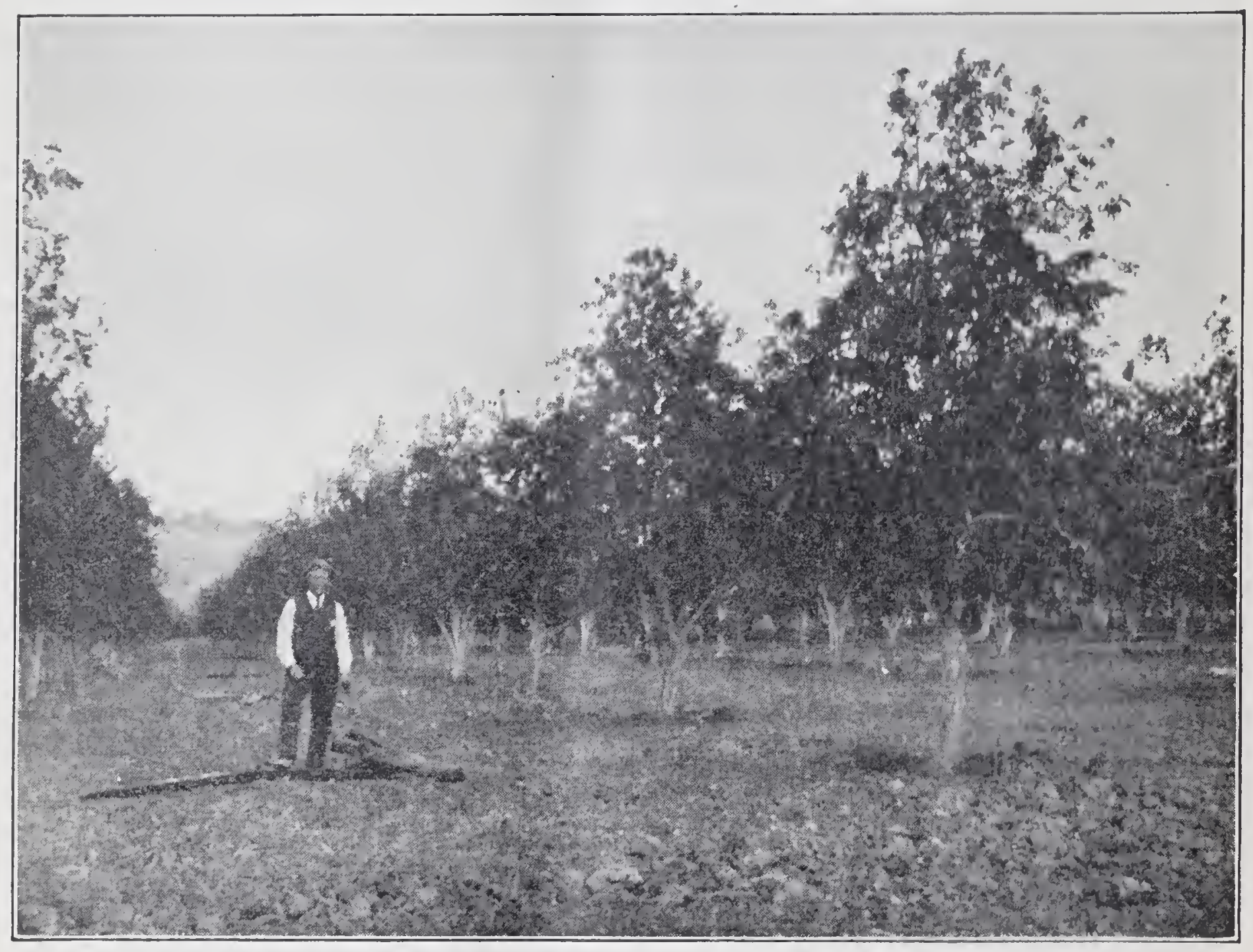

FIG. 1.-Old fence rails used sucessfully for firing in saving the Bartlett pear crop of Mr. J. (i. (Gore in the Rogue River Valley, Oregon.

firings are required during the season. Usually it is never necessary to fire more than once or twice during the season, but during certain seasons it may become necessary to fire four or five times.

The material for building these fires, especially where brush and wood are to be the fuel used, should be piled up along the side of the fick and, if necessary, covered to keep it dry so that it will ignite readily. This work may be done at any time during the summer or winter, whenever there is any spare time. Usually there are times when this work can be done without any real loss of time, 
since the men may not be able to do anything else with profit. At any rate, one should have a plentiful supply of fucl on hand and be sure that it is near by where it can be readily distributed and that it is in a dry condition so that it can be readily ignited. The writer has known of failures in firing where the grower failed to keep his material in shape for immediate use.

\section{MATERIALS TO BE USED FOR FUEL.}

The materials which may be used for fuel depend largely upon local conditions. In some places the use of wood may be entirely out of the question. However, there is a choice in the use of coal, crude oil, straw, stable manure, or any rubbish which usually accu-

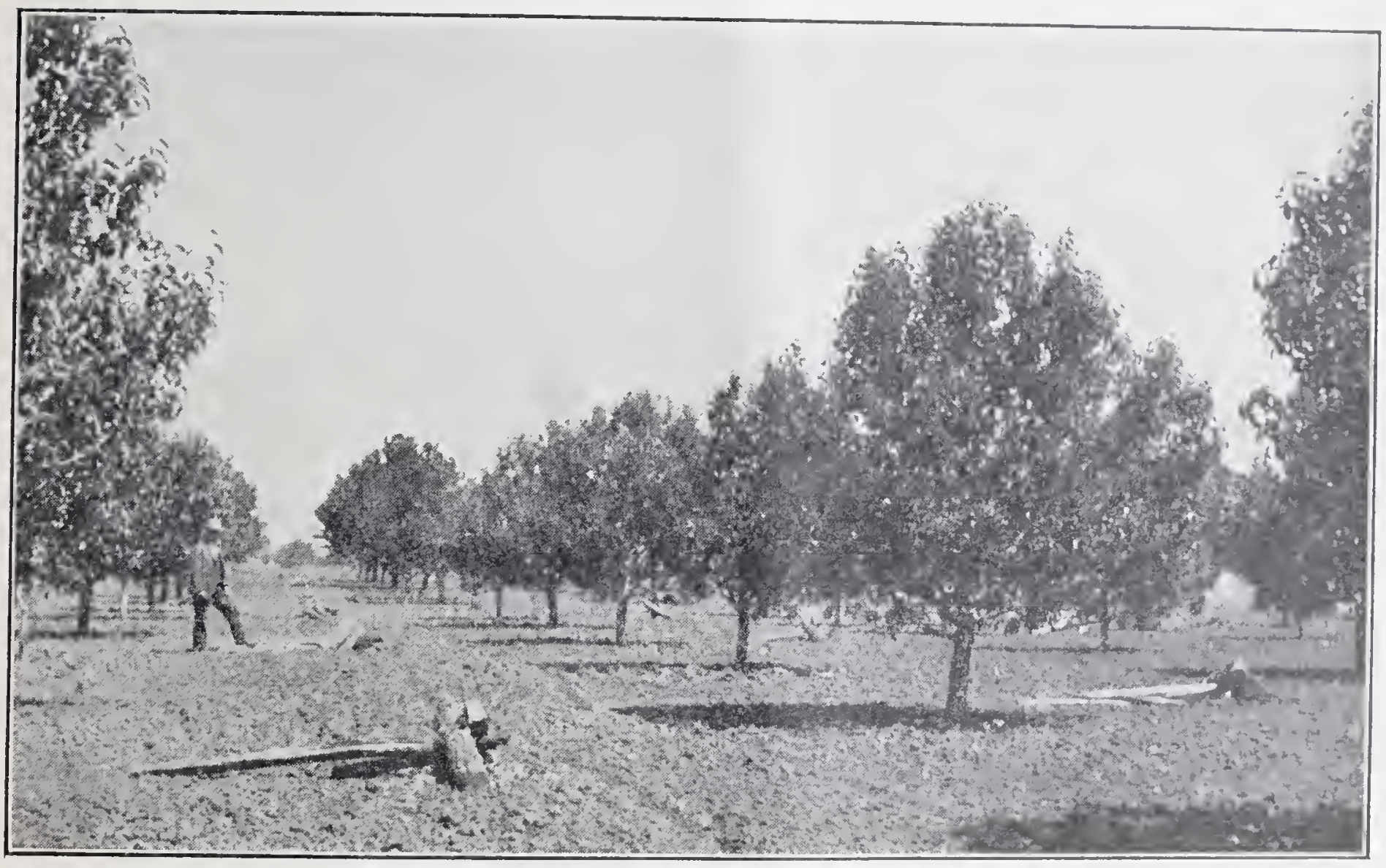

FIG. 2.- Old rails used for firing to save the crop of the 7-year old apple orchard of Mr. J. (i. Gore in the Rogue River Valley, Oregon.

mulates around the farm. In the experiments in the Rogue River Valley, while there was some variety in the matter of fucl, wood was principally used. In some cases good fir and even oak cordwood was used. In other cases old rails from fences which had becn torn down, small brush wood, and even prunings from the orchard were used. In the Bartlett pear orchard of MIr.J. G. Gore the crops were saved for two years in succession by the use of old fence rails, as illustrated in figure 1. Old rails were also successfully used in saring the crop of a 7-year-old apple orchard (see fig. 2). There are usually not enough prunings in any one orchard to be worth anything except for use in starting the fires quickly, for which purpose they are valuable if kept very dry. 
Crude oil was used only to a very limited extent. 'The Southern Pacific Company very kindly gave a considerable quantity of their crude locomotive-fuel oil from their tanks at Ashland, Oreg., to the growers for experimental use. It was found, however, that since this oil contains a considerable quantity of water, due to the fact that it is pumped from the oil fields through pipes having a water jacket, it is very hard to ignite and even after igniting fails to burn well. This oil was used in different kinds of pots and burners with about equal success. In most cases the fires went out shortly after lighting or the contents exploded in the pots. Although the crude oil could not be used as a fuel, it was found very valuable for satu-

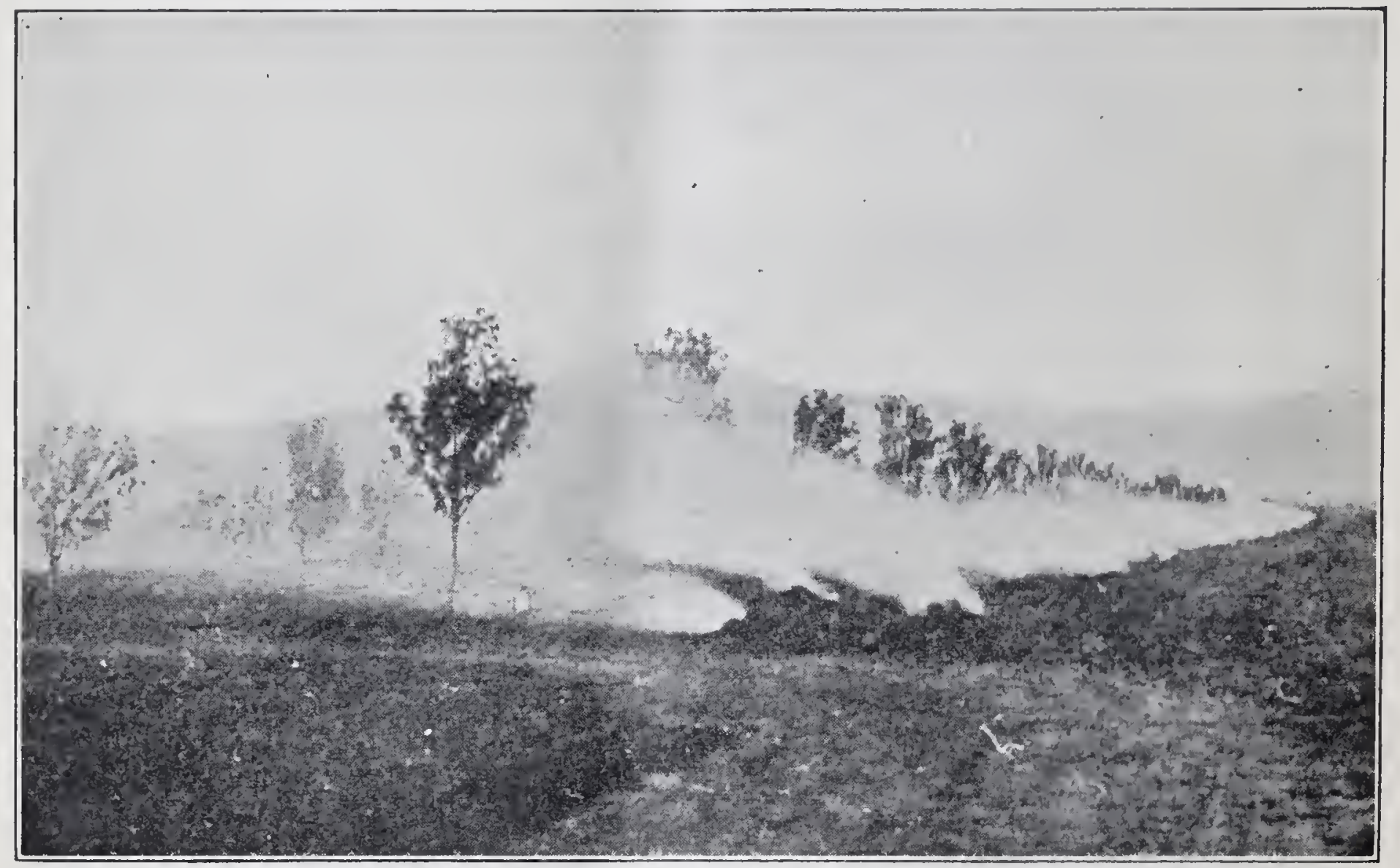

Fig. 3.-View in the Hollywood orchards, Medford, Oreg., at 5 a. m., $\Lambda$ pril 21, 1909, showing the smudging used to prevent frost injury.

rating shavings or other fine materials which were used in starting the fires. This will be considered in detail later.

Stable manure, straw, and rubbish were also employed, but only to a very limited extent. These materials were principally used for producing a dense smudge, with the idea of protecting the orchards from the direct rays of the sun in the early morning after it was known that there had been some freezing of the blossoms. The idea in nearly every case was not to raise the temperature of the air in the orchards, as was the case with the use of wood, but simply to form a heavy smoke blanket which would prevent the blossoms from warming up too rapidly in case they were slightly frozen. Figure 3 represents the smudging employed in the Hollywood orchards, Medford, Oreg., at 5 o'clock in the morning on April 21, 1909.

Another valuable material which was used only in a few cases is the lignite coal which is mined near Medford. This coal, although 
not igniting very readily, was found to be of considerable value if used in connection with wood. In using the coal it was usually placed on top of the wood piles and was found to be a grood heat producer. Undoubtedly it will be found very valuable where fires must be prolonged for some time during very cold nights.

\section{MATERIALS FOR STARTING FIRES.}

In the experiments conducted by the writer the materials used for starting the fires varied about as widely as the materials used in maintaining the fires.

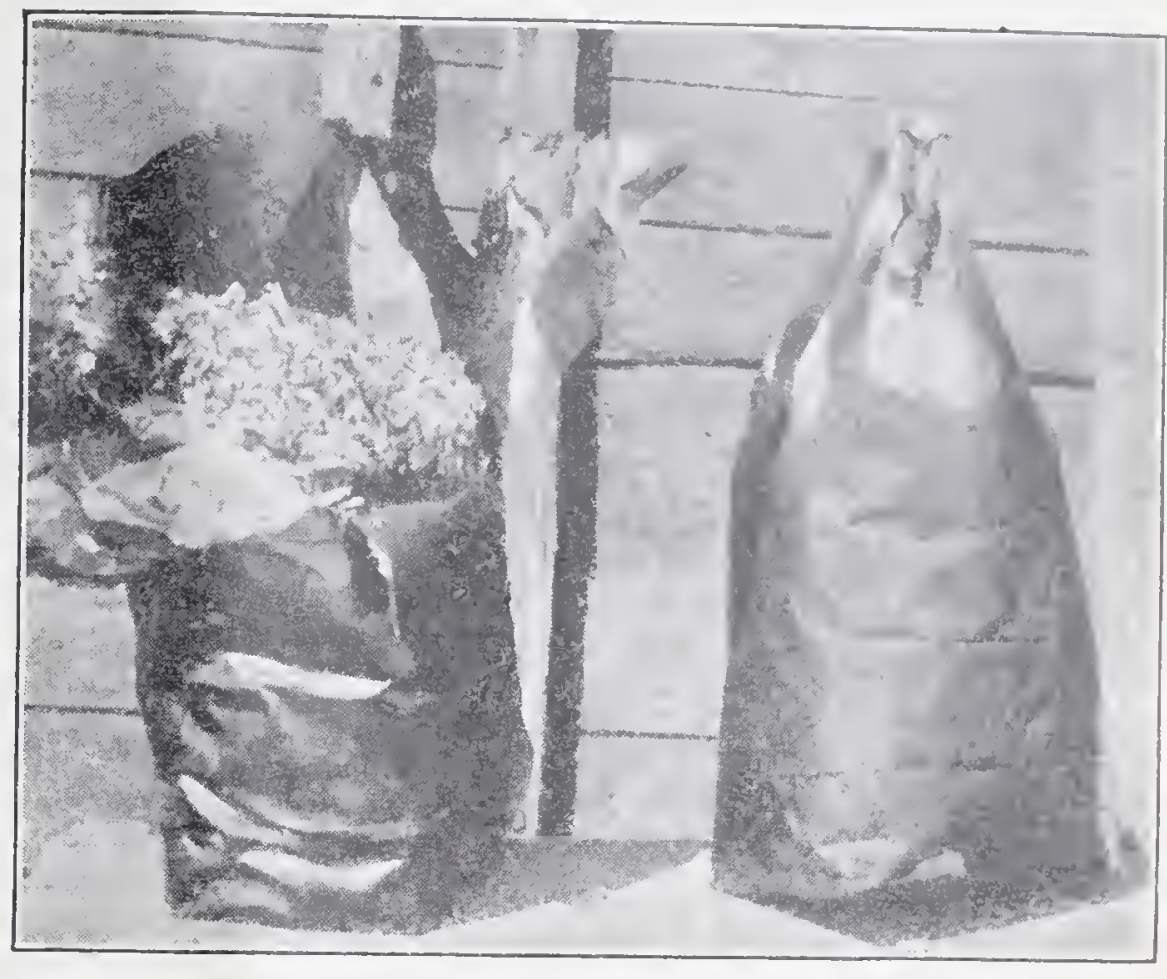

FIG. 4.-Paper sacks filled with shavings and sawdust saturated with crude fuel oil.

These materials consisted of shavings or mill planings, sawdust, straw, crude oil, light brush, and rubbish or rakings from the adjoining woods. One of the best materials was found to be mill planings,

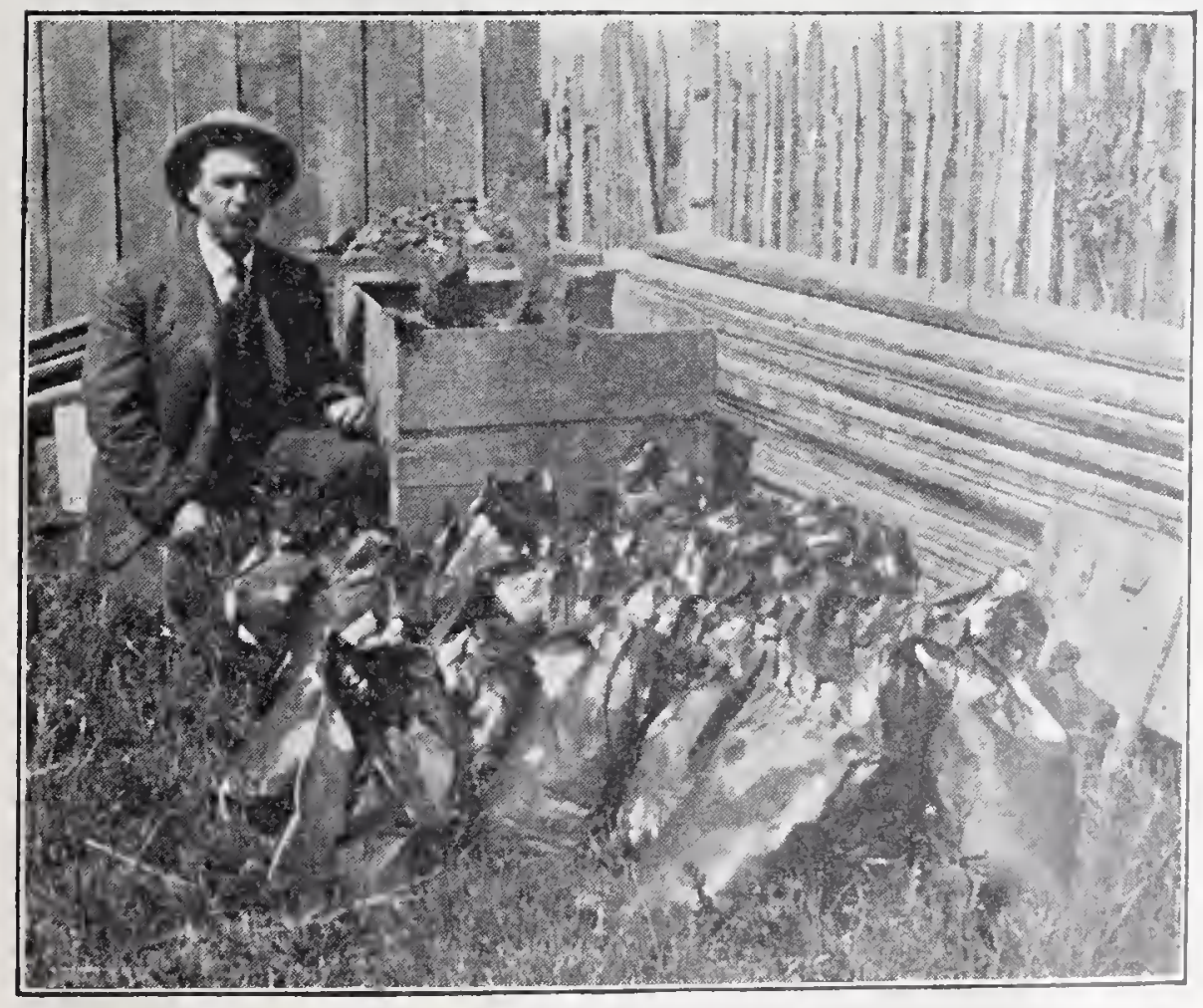

FIG. 5.-A supply of paper sacks filled with shavings and saturated with crude fuel oil to be used for starting fires. which were put into medium-sized p a p e r sacks and the whole saturated with crude oil or kerosene. A considerable number of these bags were prepared beforehand and kept in a shed, where they were readily available when it was necessary to build the fires. Sawdust mingled with tar was also used, but it was found to be harder to handle and not so casily marle up as the

bags of shavings. Figures 4 and 5 show the bags used in starting the fires. Pine leaves and other forest leaves may be used for this purpose.

38302-Bul. 401-10-2 
In some cases, instead of using shavings or very light material of any kind, kerosene was poured directly on the coarse material and then ignited with a match or a torch. This method, however, is more expensive than the former, and unless the wood or other material is very dry the fires will not start. One of the most important factors in firing is to get the fires lighted as rapidly as possible whon the temperature begins to drop or approaches the danger point. Of course where there is only a small acreage this is not quite so urgent as where there is a considerable amount of ground to be gone over. With the use of kerosene torches and with the fires already laid, it was found that the fires for an acre could be lighted by one man in from seven to ten minutes. The use of a kerosene or gasoline torch

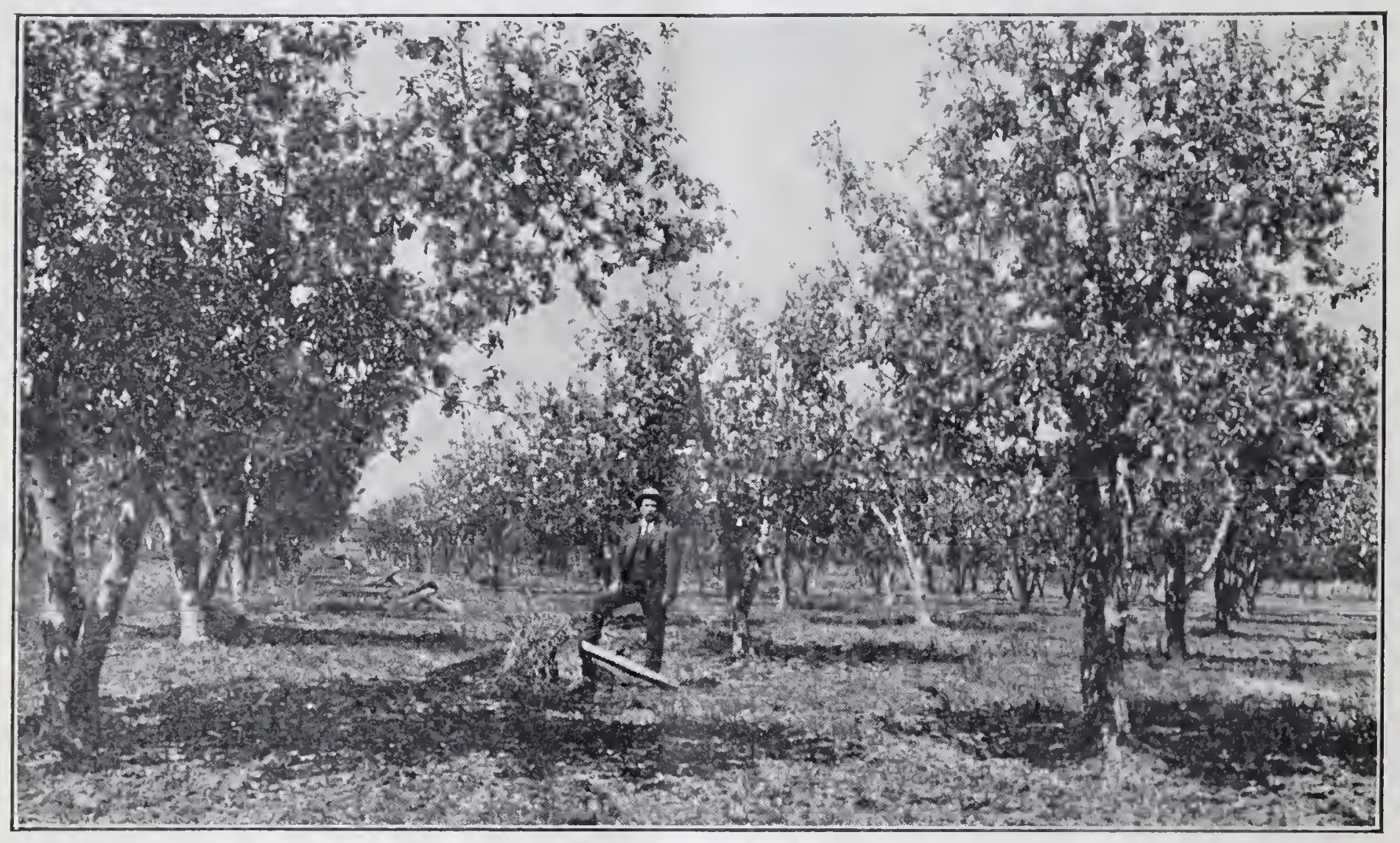

FIG. 6.-Arrangement of cordwood in the Yellow Newtown apple orchard of Mr. W. II. Brown in the Rogue River Valley, Oregon.

is advisable for the reason that it does not readily blow out. With such a device one can light the fires almost as rapidly as he can run.

\section{MANNER OF DISTRIBUTING THE MATERIALS IN THE ORCHARD.}

The number of heaps or piles of material which should be distributed in the orchard will vary somewhat, depending upon the kind of material used, about forty to fifty piles per acre being usually sufficient. In most cases a heap or pile was placed between every four trees-that is to say, a pile every other tree row in each direction in the orchard. The arrangement of cordwood in the apple orchard of Mr. W. H. Brown is shown in figure 6. Figure 7 illustrates a similar arrangement in an Esopus (Spitzenberg) apple orchard. Gener401 
ally it will be found that only half of these heaps will have to be lighted at one time, which of course allows a large amount of reserve material that may be used in case it is impossible to keep the temperature up with only half the fires lighted.

It is also well to place heaps of fuel on the outer edges or borders of the orchard, since it is often found that the outside trees may suffer where a slight breeze tends to blow the heat away. These piles should be distributed outside the last row of the orchard, and in case the temperature can not be kept up they should be lighted. Figure $s$ shows the distribution of piles on the outside borders of the pear orchard of Mr. A. C. Allen, Medford, Oreg.

In case the temperature can not be kept up to $28^{\circ} \mathrm{F}$, a certain

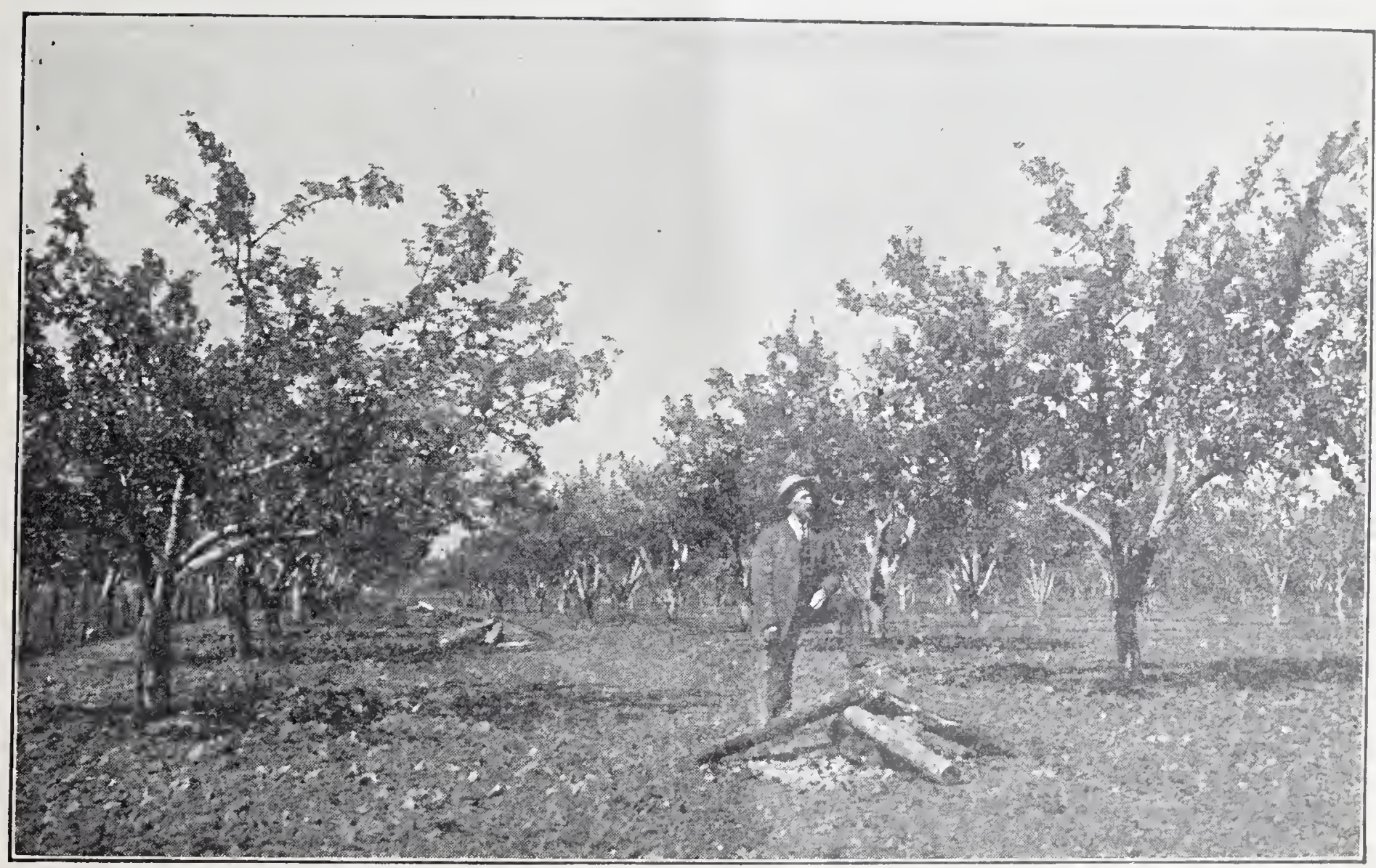

Fig. 7.-Arrangement of cordwood in the Esopus orchard of Mr. W. H. Brown in the Rogue River Yalley, Oregon.

amount of straw or stable manure, which will produce a dense smudge, should be placed upon these heaps before the sun rises in order to prevent the slightly frozen fruit or blossoms from thawing out too rapidly. These smudges should be started on the side or sides from which the wind is blowing and the material should be wet, so as to make it burn without any flame.

\section{QUANTITY OF MATERIAL TO BE USED FOR EACH FIRE.}

Experience has shown that the fires should not be linge, since large fires tend to produce convective currents that are apt to bring in cold air; hence, the quantity of material for each heap need not be very great. Large fires also might scorch the blossoms. From 401 
four to five pieces of cordwood, or its equivalent in any other kind of wood or old rails, are sufficient for a single fire; very often when the low temperature is of short duration all of this material will not be consumed in a single firing. Figure 9 shows the piles of fir cordwood with dry pruning's used in firing the apple orchard of Mr. W. H. Brown. In case stable manure or rubbish was used a larger number of heaps were placed, and the quantity of material to each heap averaged about a bushel or a bushel and a half.

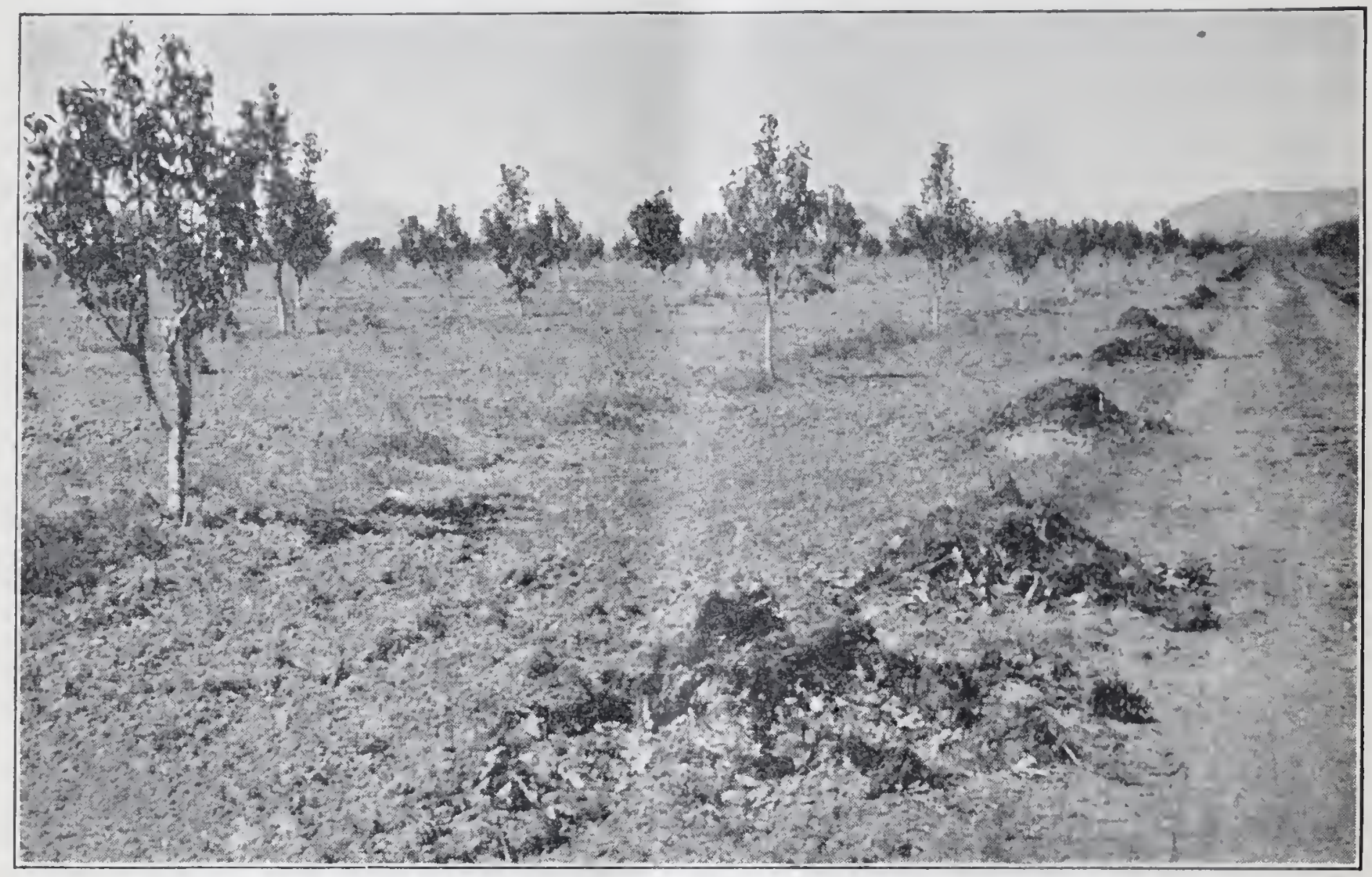

FIG. S.-Arrangement of material on the outside borders of the pear orchard of Mr. $\Lambda . C$. Allen in the Rogue River Valley, Oregon.

\section{COST OF MATERIALS FOR FIRING AN ACRE.}

The cost of the material for firing varied greatly, depending upon how it was obtained. In some cases where good cordwood was used the cost of one firing was given as $\$ 2$ per acre. Mr. W. H. Brown, who used good fir cordwood, states that when using from five to seven sticks in a pile every second row one way and every fourth row the other the cost per acre for three hours' firing approximated 60 cents. However, it may be stated that generally the cost per acre for one night was between $\$ 2$ and $\$ 2.50$. In some cases the cost was estimated as high as $\$ 4$, but it is quite possible that more material than was necessary was burned and that a higher price than usual was paid for it. Where stable manure and rubbish alone were used the cost for firing per acre was from 4 to 10 cents. 'This was because the material was on hand and the only element of expense was for distributing it. 
The cost of labor for firing an acre also varied, but a good sencril average would be about $\$ 1$. Of course this item of expense varied with the type of material used as well as with the distance that it was necessary to haul it.

\section{NECESSITY OF UNDERSTANDING WEATHER CONDITIONS.}

Before efficient work can be done in frost prevention a thorough understanding of local weather conditions must be had. In other words, the grower should know when to smudge or fire in the orchards. Unless he knows beforehand that freezing temperatures may be expected, the opportunity for firing at the right time may be lost.

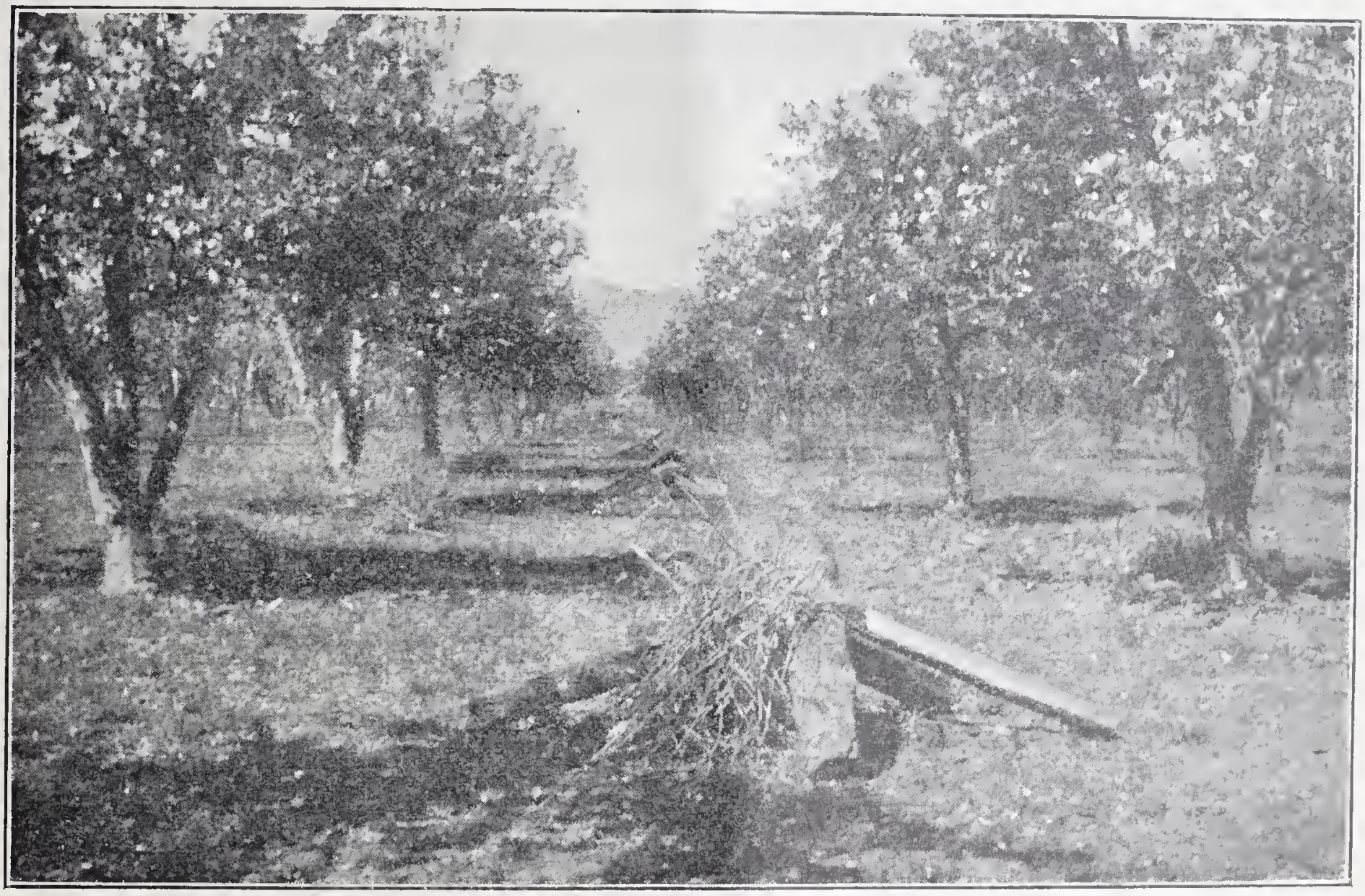

FIG. 9. - Fir cordwood with dry prunings used for firing in the apple orchard of Mr. W. H. Brown in the Rogue River Valley, Oregon.

Again, unless he is reasonably certain low temperatures will occur during the night, he may waste a considerable quantity of costly material when there would be no real need of it.

In order to carry on the work of frost prevention successfully, daily weather reports or the weather map, preferably both, should be available. In many localities the use of a weather map would be out of the question, since it may be at least twenty-four hours old and of very little value when it is received. Especially on the Pacific coast there is very little gained by using a map that is so old. In case the map can not be used, telegraphic reports should be received every day. During the time that the writer was at work on frost prevention in the Rogue River Valley, weather maps were 
received from the Weather Bureau station at Sacramento, (al., through the kindness of Mr. N. R. 'Taylor, observer. Mr. 'Taylor' also gave valuable advice in regard to conditions on the Pacific coast, especially in the small, inclosed valleys which are surrounded by high mountains. The Weather Bureau office at Portland, Oreg., kindly furnished telegraphic reports to the Medford Commercial Club, and weather signals were hoisted. The assistance from both of these Weather Bureau offices was of the greatest importance in carrying out the work successfully.

Of equal importance with the general forecasts given by the Sacramento and Portland stations were the local observations and forecasts of the writer, made necessary by the absence of a Weather Bureau observer. In a valley situated as is the Rogrue River Valley, local conditions and surroundings influence to a considerable degree the temperature, air currents, relative humidity, etc. It was found that the most important thing to the grower was the immediate local forecast made every evening about sundown. An inspection of the record of observations made at Medford, Oreg., during the months of April and Nay, 1909, as presented in the following table, will show the nature of this work:

Table I.-Record of weather obsermations at Medford, Oreg., during A pril and May, 1909. Reudings referred to psychrometric tables for a barometric pressure of 29 inches.

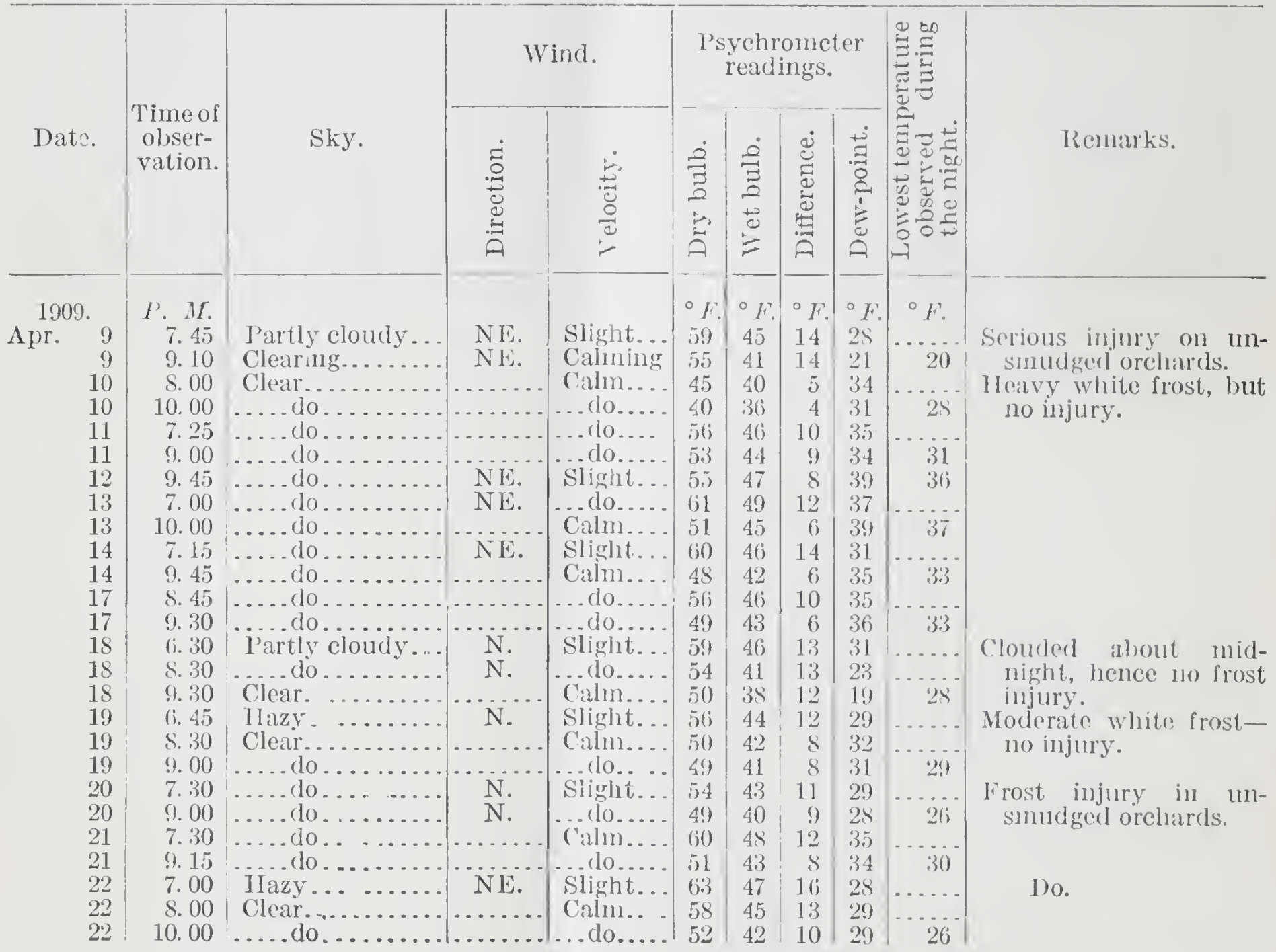


TABLE I.-Record of weather observations at Medford, Oreg., during A prit and LHay, 1909 Realings referred to psychrometric tables for a barometric pressure of 29 inches-Cont'd.

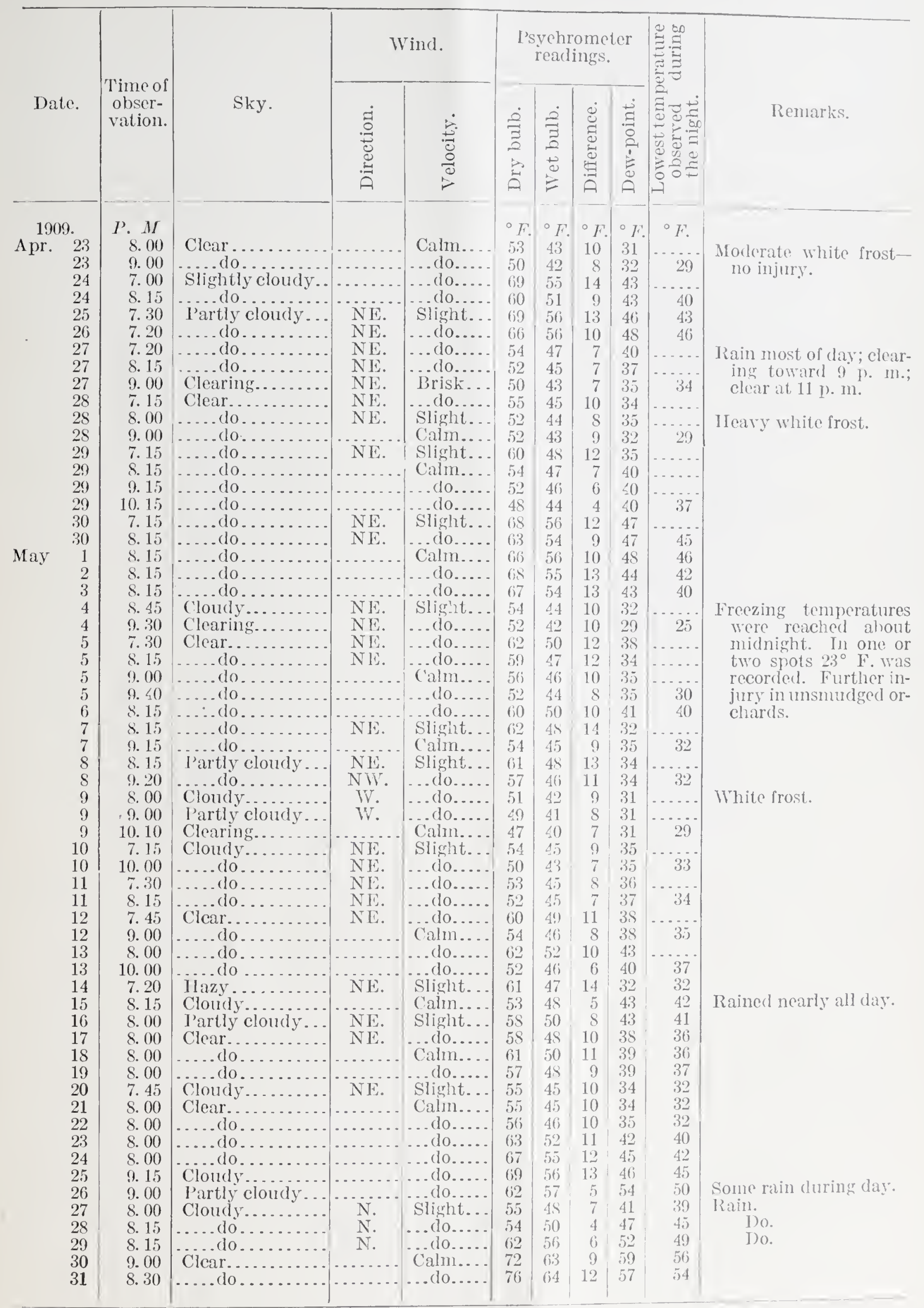


In some cases it will be noticed that several observations were made throughout the evening, so as to determine the trend of local weather conditions. The most important observations were those made with the psychrometer, an instrument for measuring the quantity of water vapor in the atmosphere, this vapor determining to a very great extent whether or not frost may be expected. The psychrometer is made of two thermometers, one bulb being covered with a piece of thin muslin cloth and the other left exposed (see fig. 10). The cov-

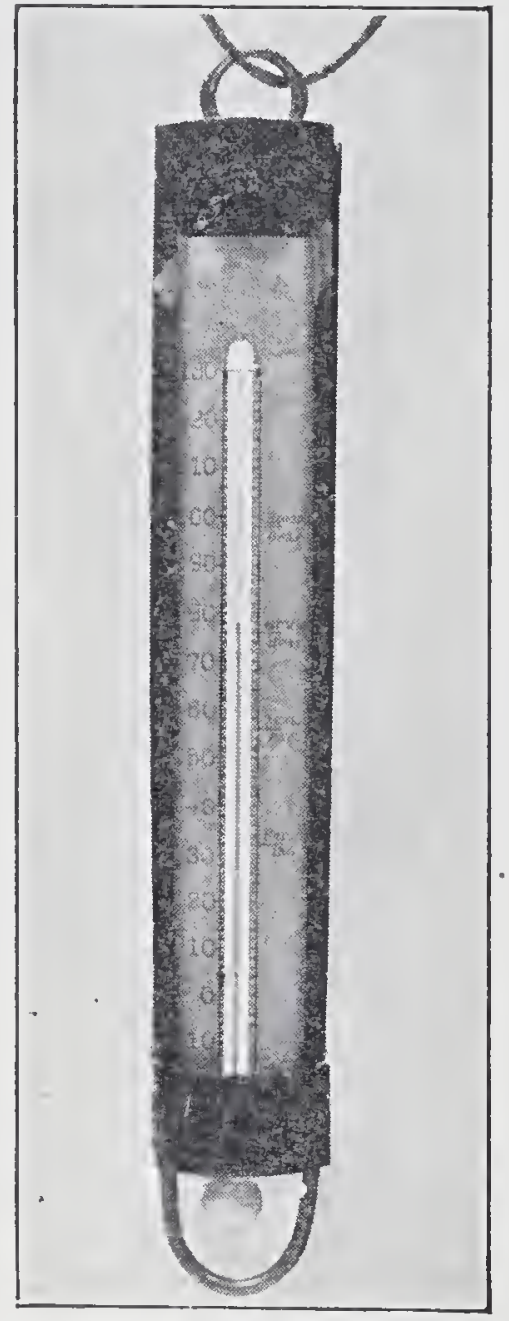

Fig. 10.-A homemade psychrometer showing the wet bulb extending below the frame, protected by a heary wire loop.

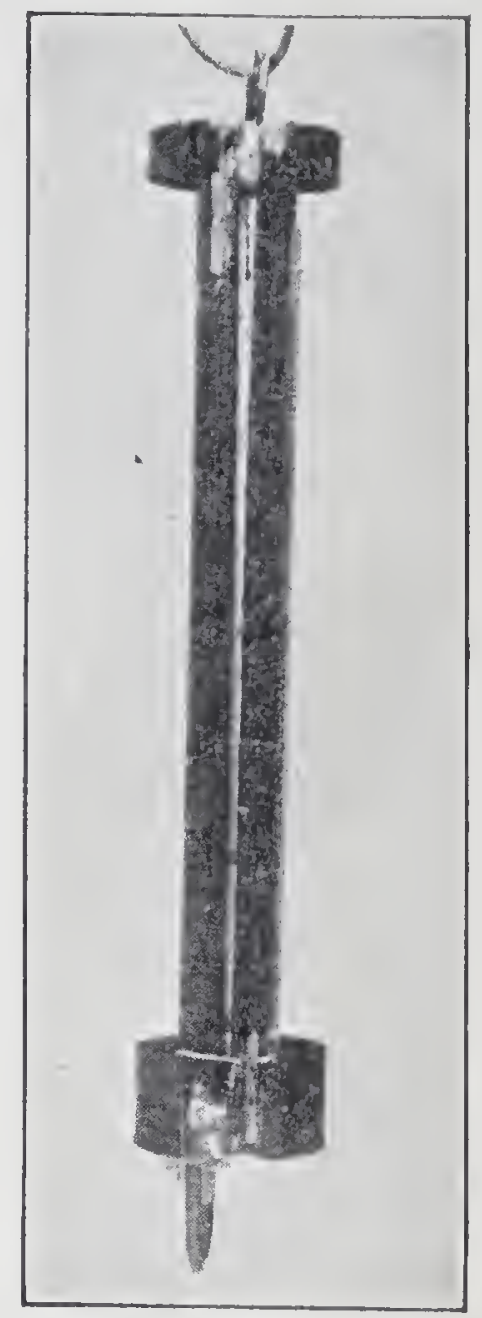

Fig. 11.-Side view of a homemade psychrometer showing backs soldered together.

ered bulb is wet and the instrument whirled rapidly so as to produce evaporation from the wet bulb. The temperatures of the two bulbs are read when the wet bulb has reached its lowest point and the difference between the two readings taken. These readings are then referred to tables published by the United States Weather Bureau showing the dew-point, i. e., the temperature at which dew or frost will form, a reprint of which follows: 
TABLE II.-For determining the temperature of dew-point in degrees Fahenheit.

\begin{tabular}{|c|c|c|c|c|c|c|c|c|c|c|c|c|c|c|c|}
\hline \multirow{2}{*}{$\begin{array}{l}\text { Dry- } \\
\text { bulb } \\
\text { ther- } \\
\text { mom- } \\
\text { eter. }\end{array}$} & \multicolumn{15}{|c|}{ Dew-point when the difference between the wet-bulb and dry-bulb temperatures is- } \\
\hline & $1^{\circ}$ & $2^{\circ}$ & $3^{\circ}$ & $4^{\circ}$ & $5^{\circ}$ & $6^{\circ}$ & $7^{\circ}$ & $8^{\circ}$ & $9^{\circ}$ & $10^{\circ}$ & $11^{\circ}$ & $12^{\circ}$ & $13^{\circ}$ & $14^{\circ}$ & $15^{\circ}$ \\
\hline$\circ \mathrm{F}$. & ${ }^{\circ} \mathrm{F}$. & ${ }^{\circ} F$. & ${ }^{\circ} \mathrm{F}$. & ${ }^{\circ} \mathrm{F}$. & ${ }^{\circ} \mathrm{F}$. & $\circ \mathrm{H}$. & ${ }^{\circ} F$ & ${ }^{\circ} \mathrm{F}$. & ${ }^{\circ} \mathrm{F}$. & ${ }^{\circ} F$. & $\circ k$ & $\circ F$ & ${ }^{\circ} F$ & $\circ F^{\circ}$ & $\circ$ \\
\hline 35. & 33 & 30 & 28 & 25 & 22 & 18 & 14 & 8 & $i$ & -8 & $-2 \dot{8}$ & & I & $F$. & ${ }^{\circ} \mathrm{F}$ \\
\hline 36. & 34 & 31 & 29 & 26 & 23 & 20 & 15 & 11 & 4 & -4 & -19 & & & & \\
\hline 37. & 35 & 32 & 30 & 27 & 24 & 21 & 17 & 13 & 7 & -1 & -12 & $-44^{4}$ & & & \\
\hline 38. & 36 & 33 & 31 & 28 & 26 & 23 & 19 & 14 & 9 & 3 & -7 & -25 & & & \\
\hline $\begin{array}{l}39 . \\
40\end{array}$ & $\begin{array}{l}37 \\
38\end{array}$ & $\begin{array}{l}34 \\
35\end{array}$ & $\begin{array}{l}32 \\
33\end{array}$ & $\begin{array}{l}29 \\
31\end{array}$ & $\begin{array}{l}27 \\
28\end{array}$ & 24 & 21 & 16 & 12 & 6 & -3 & -16 & & & \\
\hline $41 \ldots$ & $\begin{array}{l}50 \\
39\end{array}$ & 37 & 34 & $\begin{array}{l}01 \\
32\end{array}$ & 29 & $\begin{array}{l}25 \\
26\end{array}$ & $\begin{array}{l}22 \\
23\end{array}$ & $\begin{array}{l}18 \\
20\end{array}$ & 14 & 8 & 1 & -10 & -35 & & \\
\hline $42 \ldots$ & 40 & 38 & 35 & 33 & 30 & 28 & $\begin{array}{l}23 \\
25\end{array}$ & $\begin{array}{l}20 \\
21\end{array}$ & $\begin{array}{l}16 \\
17\end{array}$ & $\begin{array}{l}11 \\
13\end{array}$ & 4 & $\begin{array}{l}-5 \\
-1\end{array}$ & -21 & & \\
\hline $43 \ldots$ & 41 & 39 & 36 & 34 & 31 & 29 & 26 & 23 & 19 & $\begin{array}{l}15 \\
15\end{array}$ & 10 & $\begin{array}{r}-1 \\
-1\end{array}$ & $\begin{array}{r}-13 \\
-7\end{array}$ & $\begin{array}{l}-59 \\
-39\end{array}$ & \\
\hline $44 \ldots$ & 42 & 40 & 38 & 35 & 32 & 30 & 27 & 24 & 21 & 17 & 12 & $\begin{array}{l}3 \\
6\end{array}$ & $=2$ & $\begin{array}{l}-28 \\
-17\end{array}$ & \\
\hline $45 \ldots$ & 43 & 41 & 39 & 36 & 34 & 31 & 29 & 26 & 22 & 19 & 14 & 8 & 2 & -9 & -37 \\
\hline $46 \ldots$ & 44 & 42 & 40 & 37 & 35 & 32 & 30 & 27 & 24 & 20 & 16 & 11 & 5 & -4 & -20 \\
\hline $47 \ldots$ & 45 & 43 & 41 & 39 & 36 & 34 & 31 & 28 & 25 & 22 & 18 & 13 & 8 & 0 & -12 \\
\hline 48... & 46 & 44 & 42 & 40 & 37 & 35 & 32 & 30 & 27 & 23 & 20 & 15 & 10 & 4 & $-i$ \\
\hline $49 \ldots$ & 47 & 45 & 43 & 41 & 39 & 36 & 34 & 31 & 28 & 25 & 21 & 17 & 13 & 7 & -2 \\
\hline 50. & 48 & 46 & 44 & 42 & 40 & 37 & 35 & 32 & 29 & 27 & 23 & 19 & 15 & 9 & 2 \\
\hline $51 \ldots$ & 49 & 47 & 45 & 43 & 41 & 39 & 36 & 34 & 31 & 28 & 25 & 21 & 17 & 12 & 6 \\
\hline 52. & 50 & 48 & 46 & 44 & 42 & 40 & 37 & 35 & 32 & 29 & 26 & 23 & 19 & 14 & 9 \\
\hline $53 \ldots$ & 51 & 49 & 47 & 45 & 43 & 41 & 39 & 36 & 34 & 31 & 28 & 24 & 21 & 16 & 11 \\
\hline 54 & 52 & 50 & 49 & 47 & 44 & 42 & 40 & 38 & 35 & 32 & 29 & 26 & 23 & 19 & 14 \\
\hline $55 \ldots$ & 53 & 52 & 50 & 48 & 46 & 43 & 41 & 39 & 36 & 34 & 31 & 28 & 24 & 21 & 16 \\
\hline 56 & 54 & 53 & 51 & 49 & 47 & 45 & 43 & 40 & 38 & 35 & 32 & 29 & 26 & 23 & 19 \\
\hline $57 \ldots$ & 55 & 54 & 52 & 50 & 48 & 46 & 44 & 42 & 39 & 36 & 34 & 31 & 28 & 24 & 21 \\
\hline 58 & 56 & 55 & 53 & 51 & 49 & 47 & 45 & 43 & 40 & 38 & 35 & 32 & 29 & 26 & 22 \\
\hline 59. & 57 & 56 & 54 & 52 & 50 & 48 & 46 & 44 & 42 & 39 & 37 & 34 & 31 & 28 & 24 \\
\hline $60 \ldots$ & 58 & 57 & 55 & 53 & 51 & 49 & 47 & 45 & 43 & 41 & 38 & 35 & 32 & 29 & 26 \\
\hline 61 & 59 & 58 & 56 & 54 & 52 & 51 & 49 & 46 & 44 & 42 & 39 & 37 & 34 & 31 & 28 \\
\hline 62. & 60 & 59 & 57 & 55 & 54 & 52 & 50 & 48 & 46 & 43 & 41 & 38 & 35 & 32 & 30 \\
\hline 63. & 61 & 60 & 58 & 56 & 55 & 53 & 51 & 49 & 47 & 45 & 42 & 40 & 37 & 34 & 31 \\
\hline $64 \ldots$ & 62 & 61 & 59 & 58 & 56 & 54 & 52 & 50 & 48 & 46 & 44 & 41 & 38 & $3 t i$ & 33 \\
\hline 65 & 63 & 62 & 60 & 59 & 57 & 55 & 53 & 51 & 49 & 47 & $4 i$ & 43 & 40 & 37 & 34 \\
\hline 66. & 64 & 63 & 61 & 60 & 58 & 56 & 54 & 53 & 51 & 48 & 46 & 44 & 42 & .39 & 36 \\
\hline 67. & 65 & 64 & 62 & 61 & 59 & 57 & 56 & 54 & 52 & 50 & 48 & 45 & 43 & 40 & 38 \\
\hline CS. - & 67 & 65 & 63 & 62 & 60 & 58 & 57 & 55 & 53 & 51 & 49 & 47 & 44 & 42 & 39 \\
\hline 69. & 68 & 66 & 64 & 63 & 61 & 60 & 58 & 56 & 54 & 52 & 50 & 48 & 46 & 43 & 41 \\
\hline 70 & 69 & 67 & $66^{\circ}$ & 64 & 62 & 61 & 59 & 57 & 55 & 53 & 51 & 49 & $4 \bar{\imath}$ & $4 i$ & 42 \\
\hline
\end{tabular}

A complete description of the psychrometer, with directions for using it, was given in the Yearbook of the United States Department of Agriculture for 1908 by Mr. Dewey A. Seeley, in a paper entitled "Instruments for Making Weather Observations on the Farm." Other instruments, such as the barometer', rain gauge, and thermometer, and their uses are also explained in this article.

\section{METEOROLOGICAL DATA OBTAINED IN THE ROGUE RIVER VALLEY.}

It is well known to meteorologists, and can be seen upon inspection of Table I, that there is a very close relation between the dew-point of the evening and the minimum temperature of the night. For instance, at 9.10 p. m., on April 9, the dew-point recorded was $21^{\circ} \mathrm{F}^{\mathrm{f}}$. At this time the sky, which had been partly clouded carly in the evening, began to clear, and a slight wind which-had been blowing from the northeast began to calm. The lowest temperature recorded before morning was $20^{\circ} \mathrm{F}$. in some of the lowest spots throughout the valley, although on higher ground it was somewhat above that point. Again, on April 13, at 7 p. m., with a clear sky ancl the wind 
blowing slightly from the northeast, the dew-point was $37^{\circ} \mathrm{F}$. The minimum temperature recorded during the night was $37^{\circ} \mathrm{F}$.

By a careful inspection of the last two columns of figures in 'Table I it will be seen that the dew-point recorded in the evening was not far at any time from the lowest temperature recorded during the night following. In one instance only, and that on $\Lambda$ pril $1 S$, was there a rather wide divergence from this general rule. By referring to the table it may be seen that the dew-point at 9.30 p. m. was $19^{\circ} \mathrm{F}$., and the minimum temperature recorded during the night was $28^{\circ} \mathrm{F}$. The reason for this was that the sky became clouded about midnight, thus preventing further radiation of heat from the yround. The warnings given out on this particular evening were based on weather conditions reported by the Portland Weather Bureau station, as well as on the weather map which had been received from Sacramento, Cal. The fruit growers were advised that it would not be necessary to build fires in their orchards, as it was very likely that the sky would become clouded before any serious lowering of the temperature had taken place. As a matter of lact the temperature recorded, $28^{\circ} \mathrm{F}$., lasted only a very short time, perhaps not more than half an hour, when the thermometer ayain began to rise. Table I, which it will be worth while looking over carefully, is selfexplanatory. The method of keeping such records is not very diffcult; henee, further explanation will not be necessary.

In giving out weather warnings it is quite important that there should be a good rural telephone system. Local conditions often change so rapidly that warnings may have to be modified even during the course of an afternoon or evening. In the Rogrue River Valley the writer was particularly fortunate in having at hand the very best telephone service. While all of the growers who smudged did not have telephones of their own, appointments were made whereby several of them might get the weather reports from a neighbor who had a telephone. The area covered in the work was probably from 10 to 12 miles or more each way from the town of Medford. In two or three instances, by request, telephone messages were sent to a distance of 30 miles. In giving out the warnings it was usual to indicate as nearly as possible the time during the night whon it would be necessary to start the smurige fires. This was important to those who did not have frost alarms. By using an ordinary alar'm elock they were awakened at the hour indicated and began the work of smudging.

The frost alarm is nothing more or less than a thermometer which can be set to ring an electric bell at a given temperature, and it would be advisable for those who may need to smudge to have one, since it often saves a great deal of time and worry as well as avoids too much loss of sleep. 


\section{WEATHER CONDITIONS PRODUCING SPRING FROSTS IN THE ROGUE RIVER VALLEY.}

During the spring months it is found that during the day the wind blows mostly from the north or northeast. These winds are not moisture laden; that is to say, the relative humidity is usually rery low, often as low as 25 per cent. During the night when frosts are likely to occur the winds die down altogether or begin to blow slightly from the south. The winds from the south are also very drr, and may even tend to lower the dew-point below that observed in the early evening. In giving out the warnings this factor was taken into account. By referring to 'Table I, it will be seen that the lowest temperature recorded during each night was usually somewhat below the dew-point recorded in the evening. This was probably due to the fact that the south winds have even less moisture than those blowing from the north or northeast. In this valley whenever the winds blow from the west or northwest it is rare that frosts occur, since there is more water vapor in them.

It is only on the valley floor that any serious injury may be caused by low temperatures during the blooming period or some time thereafter. Even on the valley floor where there may be some slight clevations, no frosts occur, when serious injury may result even a lew feet below. The hillsides surrounding the valley usually escape frost altogether. However, it is on the valley floor that many of the most. profitable orchards are found; hence the necessity of preventins frost injury. It has been found that the temperature 2 to 8 feot from the ground may often register several degrees below temperatures taken at higher elevations. For instance, the writer has notal a difference of 6 degrees between two thermometers, one being abonit 4 feet from the ground and the other only 18 inches above it. Since freezing temperatures occur simply by the cold air settling in the lower spots in the valley when the air is perfectly calm, it is crident. that this is the most favorable time for maintaining fires or smudges in the orchard. High winds never oceur during the time that the temperature may be below the freezing point. It has becn previously mentioned that a slight breeze usually comes up from the south during the early morning. However, this breeze is never sufficient to more than waft the smudge through the orehalds and does not interfere to any great extent in keeping up the temperature where fires are built. It will be seen that the conditions in the valley are ideal for the prevention of injury from freezing. 


\section{INJURIOUS TEMPERATURES.}

The temperatures at which the principal orchard fruits are liable to be injured by frost are given in the following table. Some of the figures have been taken from data furnished by orchardists, but the greater part of the table is based on actual observations made on the Pacific coast by the writer. The temperatures given can not be considered as absolute, since weather conditions previous to a freeze determine to a very great extent the ability of plants to withstand low temperatures. A few days of very warm weather, together with an ample supply of soil moisture, will cause the newly formed cells of the blossoms and fruits to be filled with a watery protoplasm, or cell sap, which freezes more readily than concentrated cell sap. If a freeze follows a period of weather in which temperatures have been such as to produce slow growth, lower temperatures than those given in the table may not cause injury.

TABLE III.-Temperatures injurious to fruit when in bud, in blossom, etc. a

\begin{tabular}{|c|c|c|c|c|}
\hline linuit. & In bud. & $\begin{array}{l}\text { In blos- } \\
\text { som. }\end{array}$ & $\begin{array}{l}\text { In set- } \\
\text { ting } \\
\text { fruit. }\end{array}$ & $\begin{array}{l}\text { At other } \\
\text { times. }\end{array}$ \\
\hline 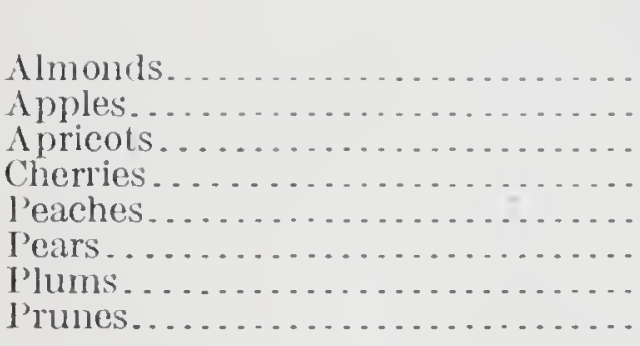 & $\begin{array}{r}{ }^{\circ} F \\
28 \\
27 \\
30 \\
29 \\
29 \\
28 \\
30 \\
30\end{array}$ & $\begin{array}{r}F^{\circ} \\
30 \\
29 \\
31 \\
30 \\
30 \\
29 \\
31 \\
31\end{array}$ & $\begin{array}{r}\circ F \\
30 \\
30 \\
31 \\
30 \\
30 \\
29 \\
31 \\
31\end{array}$ & $\begin{array}{l}\circ F . \\
28 \\
25 \\
30 \\
29 \\
28 \\
28 \\
29 \\
29\end{array}$ \\
\hline
\end{tabular}

a These temperatures are approximately those of the air in contact with the fruits and blossoms. It is quite possible, however, that very delicate measurements would indicate somewhat lower temperatures, due to evaporation from the immediate surface of the plants.

\section{RESULTS OF THE WORK.}

In the use of smudge fires where the temperature may reach as low as $20^{\circ} \mathrm{F}$., the writer has found that by using fifty wood fires per acre a temperature of $28^{\circ}$ to $29^{\circ} \mathrm{F}$. could be maintained in the orchards. In other words, the temperature could be raised 8 or 9 degrees. Where it was necessary to raise the temperature 5 or 6 degrees, only half as many fires were required. A mixture of wood and coal was probably a trifle better than wood alone. Since the coal is mined near Medford and is not very expensive it is probable that this material will be in greater demand another year should it be necessary to prevent frost injury. Crude oil was used only to a very limited extent, for the reason mentioned before - that it did not burn readily. Where it was used the temperature was not raised more than 2 or 3 degrees when forty smudge pots were burned to the acre. Straw 
and manure, which were used mostly as a smudge in the morning just before the sun came up, were intended only as a blanket to prevent the sun from warming up the blossoms too quickly. These materials were rarely used alone, since in most instances it was hardly possible to raise the temperature more than a degree or two with them. Where some sawdust which had been saturated with tar was used in connection with the straw and manure, the temperature was raised some 2 or 3 degrees with about forty fires to the acre.

The difference between the smudged and the unsmudged orchard, or even part of the same orchard remaining unsmudged, was very marked. In several instances the orchards which had been smudged set a full crop, while in those that were similarly situated and not smudged the crop was entirely destroyed. There is certainly no doubt in the writer's mind that had the growers smudged generally it would have required much less work on the part of those who did smudge. For instance, where an isolated orchardist smudged and liis neighbors did not there was a tendency for the fires to produce an upward current of air, causing cold currents to rush in and lower the temperature.

\section{VALUE OF FIRING THE ORCHARDS WHEN THE COST IS COMPARED WITH THE VALUE OF THE CROP.}

The writer has recorded several interesting statements from growers who fired and smudged successfully. Mr. W. H. Brown states that with a cost of about $\$ 6$ per acre for the season he was able to save 10 acres of apples, and estimates the value of his crop at $\$ 6,000$. The previous year one freeze which occurred on May 5 destroyed his entire crop.

Mr. G. E. Marshall makes the following statement: "The entire quantity of material used for the season was 5 pounds of crude oil (used principally in saturating shavings and other material), 1,000 old rails, 300 old stumps, 1 ton of waste bitumen, 3 tons of coal, 800 large bundles of tree prunings, 25 loads of manure, and 3 loads of planing-mill shavings. With this material I saved the crop on 9 acres of Yellow Newtown, 7 acres of Monmouth (Red Check Pippin), and about 2 acres of Jonathan apples, also 6 acres of Winter Nelis and 3 acres each of Anjou and Bartlett pears (total, 30 acres). I did not smudge 3 acres of Comice pears and they were mostly killed." Mr. Marshall does not state the value of his crop per ance, but it is doubtless no less than that of Mr. Brown's.

Mr. James W. Myers makes the statement that with a total cost of about $\$ 15$ per acre he was able to save his crop of apples. He est imates that had he not smudged, at least two-thirds of the (rop would have been lost. The crop in this orchard has brought as high as 
$\$ 1,000$ per acre, and from all appearances the same price will be equaled this year. A number of similar statements from other grower's who were just as successful might be given.

It is quite possible that in many cases some of the growers fired and smudged more frequently than was really necessary. This was done early in the season before they felt confident that weather conditions could be pretty accurately predicted. At no time during the season did the writer fail to predict frost to within a degree or two of what actually occurred. The hour at which firing would be necessary was also given out. Another year, with a well-equipped station and a competent and zealous observer in charge, in whom the growers would have confidence, the cost of smudging might be considerably reduced should it be found necessary to make use of it.

\section{PRACTICAL SUGGESTIONS ON THE USE OF THE PSYCHROMETER AND OTHER IETEOROLOGICAL INSTRUMENTS.}

Wherever it is found necessary to protect orchards from frost injury, each fruit grower should provide himself with the following apparatus:

(1) A psychrometer with tables for determining dew-point temperatures. This instrument may be purchased from a number of reliable concerns in the United States for from $\$ 4$ to $\$ 5$.

Although it is advisable to purchase a high-grade instrument for making dew-point determinations, a very serviceable instrument may be made by the average person at a very moderate cost. An illustration of this instrument is shown as figure 10. Procure two fairly good thermometers of the kind with the scale marked on a strip of metal which is attached to the tube by means of small wire clamps. The bulb and scale are removable from the tin protective shield. Slide one of the thermometers with its attached scale downward so that the bulb projects below the lower end of the frame. Fix the thermometers in the frame so that they will not slide out when the instrument is whirled. This may be done by drilling small holes through the frame and scale and binding the two together with wire. The two thermometers are now fixed together back to back by soldering or by small rivets, as illustrated in figure 11. A piece of heavy wire bent in the form of a $U$ should be soldered to the lower end of the wet-bulb frame as a protection against accidental breakage. The projecting bulb must now be covered with thin muslin eloth. A string or leather thong about 2 feet long should be tied in the rings, which are soldered to the top of the instrument. This string serves as a means with which to whirl the thermometers. After using the psychrometer a few times the linen cloth should be changed. 
In using the instrument, wet the covered bulb and whirl it rapidly so that evaporation will take place from the wet surface. The whirling should be continued until the mercury is brought as low as possible. When it can not be lowered any farther it should be read simultaneously with the dry-bulb thermometer. The temperature of the dry bulb, which is the air temperature, and the difference between it and that of the wet bulb should then be referred to Table II. It is best when using the psychrometer to take several readings and then take the mean before referring to the table. In this way greater accuracy will result. One point which should not be overlooked in the matter of selecting the thermometers is that the two instruments should read exactly alike for all temperatures, because it is the difference between the two thermometers that is of the greatest importance.

(2) Several good thermometers, which should be placed at different points in the orchard at an elevation of from 4 to 5 feet from the ground. Temperatures near the ground are always much lower than those at 4 or 5 feet higher. It is the temperature of the air which surrounds the fruiting portion of the tree that we wish to know about.

(3) A maximum and minimum thermometer. This instrument is not absolutely necessary, but it is very useful in serving as a check upon the observations made with the other thermometers.

(4) An aneroid barometer. This instrument is rather costly, being worth from $\$ 18$ to $\$ 20$, but if a single grower does not desire to buy one, several might purchase the instrument together. This instrument indicates the air pressure and the highs and lows which may be seen marked on the weather maps. During a period of high pressure the chances are that frosts may be expected, while during low pressure, which means that there is a considerable quantity of water vapor in the atmosphere, frosts are not so likely to appear. This instrument would indicate the movement of the high and low pressure of the atmosphere and act as a check upon the psychrometer observations.

(5) It would also be well to gret the daily weather maps and warnings from the nearest weather stations. These reports would indicate, at least in a general way, the kind of weather that would be likely to occur within a certain time and would give this information long enough in advance so that preparation might be made for firing in the orchards. For very small orchards preparation may be quickly made, but where the tracts are large it refuires some time. Without doubt the small tracts of, say, 10 acres or less can be much more easily and successfully handled. 


\section{CONCLUSIONS.}

(1) There is no doubt that frost injury may be prevented by the use of fires and smudges.

(2) Wood and coal have proved to be the best fuel.

(3) Where the temperature drops to $20^{\circ} \mathrm{F}$. it would seem that fifty fires per acre are necessary. Only half ás many are needed when the temperature reaches, say, 25 to $26^{\circ} \mathrm{F}$.

(4) Shavings, chips, or other fine material in paper sacks saturated with crude oil or kerosene have been found best for starting the fires quickly. Kerosene torches for lighting the fires have also proved to be very serviceable as compared with matches.

(5) Straw and stable manure are valuable for producing dense smudges, but are not effective in raising the temperature in the orchard. The value of the smudge, or dense smoke, is more to protect the trees from the early morning sun where some slight freezing of the blossoms and the fruit has occurred during the night.

(6) The cost of firing with wood and coal, including labor, should not average more than $\$ 3$ a night per acre, even where it may be necessary to keep the fires burning five or six hours. In some localities where wood can be had without expense except for the hauling, these figures might be reduced somewhat. However, in localities where wood is rather scarce they would probably be somewhat higher.

(7) The results of the past season's work in the Rogue River Valley have shown that many acres of crops valued at from $\$ 500$ to $\$ 1,000$ per acre have been saved at a total expenditure of not more than $\$ 15$ to $\$ 20$ per acre for firing. Very striking examples have been seen where unsmudged orchards adjoining those that have been smudged have borne no fruit.

[A list giving the titles of all Farmers' Bulletins available for distribution will be sent free upon application to any Member of Congress or the Secretary of Agriculture.] 